Kaygı, 18(1)/2019: 240-256. Araştırma Makalesi | Research Article

Makale Geliş | Received: 27.01.2019

Makale Kabul | Accepted: 14.02.2019

Yayın Tarihi | Publication Date: 15.03.2019

DOI: 10.20981/kaygi.539706

\author{
Ahmet KAVLAK \\ Dr. Öğr. Üyesi | Assist. Prof. Dr. \\ Yıldırım Beyazıt Üniversitesi, Felsefe Bölümü, Ankara, TR \\ Yıldırım Beyazıt University, Department of Philosophy, Ankara, TR \\ ORCID: 0000-0002-4419-9440 \\ ahmetkavlak@gmail.com
}

\title{
Hıristiyanlıkta İncil Yorumlarının Tarihsel Kaynakları *
}

Öz

Hermeneutik felsefi bir kavram olmakla birlikte asıl itibariyle dinsel kökenlidir. Felsefede yorum ve anlam sorununu ifade etmekle birlikte asıl kullanımı Hıristiyanlık teolojisinde gerçekleşmiştir. Çünkü Hıristiyanlık hem yeni bir din, hem de Yahudiliğin devamı olma iddiasında olduğu için, hem de kurucusu olan Hz. İsa'ya ilahlık vasfi da verdiği için ister istemez ortaya çıkan çelişkileri açıklama ve yorumlama ihtiyacı gerekmiştir. Bu nedenle yorum konusu en fazla Hıristiyan teolojisinde kendisini göstermiştir. Hıristiyanlık, kurucusunu ilah kabul ettiği için İncillerden daha önemli kabul eden, aynı zamanda ortaya çıktıktan bir kaç yüzyıl sonra "kutsal kitap" kavramına sahip olan ve bu "kutsal kitap” kavramını Augustinus’tan sonra kilisenin gerisinde bırakan, Hz. İsa'nın kendisinin Yahudilere gönderildiğini söylemesine rağmen putperestlere de yönelen bir din olduğu için tüm bu çelişkiler büyük bir yorum geleneğinin doğmasını gerektirmiştir. Hıristiyanlık üzerine yapılacak tüm felsefi veya teolojik çalışmalar, Hıristiyanlıktaki problemlerin tarihsel kaynaklarını göz önüne almak zorundadır. Bu aynı zamanda isabetli yorumun bir şartıdır. Bu çalışmada Hristiyanlığın tarihsel problemlerinin kökenlerine ve o problemleri temsil eden tarihi şahsiyetlerin fikirlerine ve birbirleriyle olan ilişkilerine yoğunlaşılmıştır.

Anahtar Kelimeler: Ebionitler, Havariler, Paulus, Augustinus, Yorum.

\section{Historical Resources of Biblical Interpretation in Christianity}

\begin{abstract}
Hermeneutics is originally religious as well as being a philosophical concept. Although it is related to the problem of interpretation and meaning in philosophy, its usage has in fact developed in Christian theology. Since Christianity was a new religion which attributed divinity to its founder, Jesus, and claimed to be the successor of Judaism, it was necessary to explain and interpret the contradictions that emerged. For this reason, hermeneutics has mostly appeared in the Christian theology. Christianity accepts its founder as a deity, he is seen as more important than the Bible itself. A few centuries after the bible has emerged, it attained the name 'holy book'. This term has been discarded by the Church after Augustine. In addition to these, Jesus was claimed to be sent to the Jews, yet Christianity was also oriented toward pagans. All in all, the need to solve these problems has created such a great tradition of interpretation. All philosophical or theological studies on Christianity have to take historical sources of the religion's problems into account. This is also a necessity for an accurate interpretation. This study focuses on the origins of the historical problems of Christianity, the ideas of the historical figures who represent those problems and their relations with each other.
\end{abstract}

Keywords: Ebionites, Apostles, Paulus, Augustinus, Interpretation.

* Bu çalışma, yazarının “Felsefede, Hıristiyanlıkta ve İslamiyet’te Hermeneutik” adlı “Doktora Tezi”nden üretilmiştir. 


\section{Giriş}

Hıristiyanlık düşüncesini ve yorumlarını tam anlayabilmek için ilk dönem Yahudi inancını, bu inancın içinden çıkan ilk Hıristiyanlığın tarihsel kökenlerini anlamak gereklidir. Hristiyanlık o dönemde ortaya çıkan muhtelif zit fikirlerde kökenlerini saklayan bir tarihsel yapıya sahiptir. Hem o zamandaki yerleşik dini inanç, hem idari yapı, hem de Hz. İsa'nın Yahudiler ve putperestler arasındaki konumu Hıristiyanlığın fikri ve inanç yapısının her yüzyılda yeniden yorumlanma ihtiyacının kökenlerini saklamaktadir.

\section{Hz. İsa Dönemi}

Hıristiyanlıkta yorum deyince hareket noktasının İncillerden çok, Yeni Ahid'den daha çok önemli olarak görülen Hz. İsa'nın kendisi olduğunu unutmamak gereklidir. ${ }^{1}$

Başlangıçta "Kutsal Kitap" kavramına sahip olmayan Hıristiyanlığın özellikle M.S. 300 yıllarında İznik konsülünün toplanmasına neden olan bir takım görüş ayrılıklarına rağmen burada seçilmiş olan İncillerin ilk üçü yani, Matta, Markos ve Luka genel konularda birbirlerini tasdik ederler. Bu üç incile "Synopsis İnciller” adı verilir. ${ }^{2}$ Matta İncili Hz. İsa'nın şahsının ve yaşadığı bölgenin kimliği konusu ile ilgili olup (Harrington 1991:46), Hz. İsa’nın şahsıyla ilgili bölümlerin devamında Yahudilerin Hz. İsa tarafından azarlanması, suçlanması ve küçük görülmesi gibi konular ağırlıktadır. ${ }^{3}$

\footnotetext{
${ }^{1}$ Hz. İsa'nın hayatı hakkındaki kaynakların başında İnciller ve Yeni Ahidin diğer kitapları gelmektedir. Bunlar üçüncü yüzyılın başından beri yazılan 27 risale ve mektuptur. Bunların havarilerden geldiği ve tanrının yazdırmasıyla ortaya çıktığı ve havarilerin inançlarından farklı olmadığı sonraki dönemlerde Hıristiyanlar tarafından kabul edilmiştir.

${ }^{2} \mathrm{Bu}$ üç İncil zaman bakımından Yuhanna İncilinden öncedir. Her dört incilin de verdikleri haberler sözlü rivayetlerin toparlanmasından ibarettir. İncillerin ortak özelliği, her bir cümlesini değerlendirmek, anlayabilmek için, her bir cümlenin bağlantılı olduğu olay ya da olaylarla ilgili bir kaynağın bulunmayışı1ır.

${ }^{3}$ Hıristiyanların doğru sayarak Yeni Ahide aldıkları İncillerin dışında doğru saymayarak Yeni Ahide dahil olmayan (apokryph) İncillerin en meşhurları Ebionitler ve Barnaba İncilleridir (Sarıç̧ığlu 1982:207).
} 
Hz. İsa döneminde Filistin Roma'nın bir eyaletiydi ve bağımsızlı̆̆ını M.Ö. 63'de kaybetmişti. Hz. İsa ile ilişkide bulunan resmi kimseler Romalılardı. İdare memurlarının resmi dili Latince idi. Aramca 250 seneden beri halk diliydi. İbranice sadece Tevrat'ta ve havradaki ibadetlerde kullanılıyordu. Diğer bir çok Yahudi gibi Hz. İsa da en az üç dil biliyordu.

Hz. İsa dönemindeki meşhur Yahudi grupları ise Saddukiler, Farizalılar, Esseniler'di. Saddukiler hakim zengin zümreydi. Tevrat dışındaki bütün kutsal sayılan yazıları reddederler ve her yeniliğe muhalefet ederlerdi. Farizalılar ise Tevrat dışında da sözlü rivayetlerin doğruluğunu savunurlardı. Esseniler ise Farizalılar içindeki aşırı bir grubu temsil ediyordu ve asketik ${ }^{4}$ bir hayat tercih etmişlerdi. Hz. İsa'nın da bu gruba mensup olduğu ileri sürülmüşse de ispat edilememiştir. ${ }^{5} \mathrm{Bu}$ tarikat Yahudilerin en katı kuralları bulunan, kaderi istencin özgürlüğüne yeğ tutan bir gruptu (Vermes 2005:69).

Hz. İsa'nın çıkışı takriben M.S. 28 senelerine denk gelmektedir. O dönemde münzevi olarak Ürdün steplerinde yaşayan Vaftizci Hz Yahya da Esseniler gibi şehir kültürünün dışında yaşamaktaydı.

Hz. İsa'nın daveti iki esas üzere temellenmişti. Bunlardan birincisi yakında gelecek olan İlahi Mesih Devleti ve Hakimiyeti, diğeri Şeriat meselesi (Sarıkçığlu 1982:211), yani "Yahudi dininin karşısında Hz. İsa ve taraftarlarının bu yeni öğretisinin konumu"6 idi.

\section{Hz. İsa Sonrası}

Hz. İsa döneminde davetlerin tamamı Yahudilere yönelikti. Putperestlere yönelik davetler başlangıçta Hz. İsa’ya düşman olan ve Roma adına muhbirlik yapan Sn.

\footnotetext{
${ }_{5}^{4}$ Dünyadan tamamen el etek çekme anlamında bir yaşam tarzı.

51947 yılında Lut Gölü kenarında bulunan Kurman Metinleri isimli papirüslerin bu gruba ait olması kuvvetle muhtemeldir (Sarıkçığlu 1982: 209).

${ }^{6} \mathrm{Bu}$ durum bütün Hıristiyanlık tarihi boyunca yorumların merkezinde yer alan birkaç önemli noktadan birisidir.
} 
Paulus'un ${ }^{7}$ Hıristiyanlığa girmesiyle başlamıştır. Hz. İsa'nın Yahudilere yönelik davetinin fazla taraftar bulmaması ve onların yalanlamaları, aslında Yahudi dininin bir devamı olarak ortaya çıkan bu 'Mesih Hareketi'nin ${ }^{8}$ müstakil bir cemaat olmasına ve kendi kiliselerinin oluşmasına neden olmuştur. Paulus'un Hıristiyanlığa girişi, hem ilk ihtilafların ortaya çıkmasına, hem de Mesih davetinin putperestlere de yönelmesine neden olmuştur.

Hz. İsa'nın, kendisinin Yahudi kavmine gönderildiğine dair ifadeleri vardı (Matta 15,24). Fakat Paulus kendisinin İsa tarafından putperestleri Hıristiyanlığa davetle görevlendirdiğini iddia ederek (Galatyalılara Mektup 2,9), davet alanının genişlemesine neden oldu. Fakat ilk yorumlar ilk ihtilafların da başlamasına neden oldu. Çünkü Yahudilerin dinine dayanan bu yeni cemaatin mensupları içinde bulunan çoğu putperest kökenli mensupların yeni problemlerin çözümünde nereye başvuracakları sorunu ortaya çıktı. Çünkü, Yahudi olmak ancak Yahudi bir anadan doğmakla mümkündü. Bu durumda Yahudilikten gelmeyen putperest kökenli Hıristiyanların Musa Kanunları ile, yani Yahudi dininin kuralları ile bağlı olup olmadıkları tartışma konusu oldu (Habercilerin İşleri 15,1-21). Paulus Yahudi dininin kuralları ile yalnızca Yahudi kökenlilerin sorumlu olduğunu, putperest kökenli olanların bu kurallara bağlı olmasının Yahudi dininden ayrılmamış ve Yahudi dininin boyunduruğu altına girmiş olması anlamına geleceğini iddia ederek, Hıristiyanlık inancını, putperest kökenliler için Hıristiyanlıkta hiçbir dini teklifin olmadığ 1 şeklinde yorumladı. Paulus'un bu yorumu, cemaat içindeki ilk ihtilaf kıvılcımı oldu. Yahudilikteki sünnet emri de Paulus'un itirazı nedeniyle kaldırıldı (Sarıkçıŏlu 1982: 217). ${ }^{9}$

\footnotetext{
${ }^{7}$ Paulus (asıl adı Saul) Yahudi kökenli olup Roma vatandaşı olan ve az sayıda okuma yazma bilen birisi olarak Roma İmparatorluğu adına muhbirlik yapmakta olan birisiydi.

${ }^{8}$ Yahudilerin Hz. Davud dönemindeki gibi tekrar bir Yahudi devlet kuracağına inandıkları ve gelişini bekledikleri kimse.

${ }^{9}$ Havari Petrus ve Hz. İsa'nın kardeşi Yakobus'un sünnet emrinin tatbikini istemelerine rağmen sünnet emri kaldırıldığı gibi, Paulus'un yorumlarıyla, insanı iyi eylemlerin, ibadetlerin değil sadece imanın kurtaracağı, dolayısıyla her türlü ibadetin gereksiz olduğu anlayışı kabul edildi. Putlara kesilen ve kesilmeden önce ölen hayvanların etinden yememek, yakın akraba ile evlenmemek, gayri tabii ilişkide bulunmamak kuralları (Levililer 17-18) ise aynı şekliyle kabul edildi.
} 
Hz. İsa on iki İsrail boyuna karşılık on iki havariyi seçmişti. Paulus'un Vizyonu ${ }^{10}$ ile Paulus da kendisinin havari olduğunu iddia etmişti. Bu konu başlangıçta problem olarak görülmese de, Paulus'un bir çok fikri Havarilerce tasvip edilmeyince ihtilafların doğması kaçınılmaz oldu ve havariliğin ölçütünde uzlaşma sağlanamadı. ${ }^{11}$ Paulus diğer havariler gibi sıradan balıkçılar değil, Roma vatandaşı, bir kentli ve aynı zamanda Yahudi yazılarını ve töresini bilen biriydi (Michel 1992:46). İnsanın günahkar doğduğu, iyi işlerin insanı kurtarmakta yeterli olmadığı, 'Tanrının Oğlu'12 kavramı, Kömünyon Ayini ${ }^{13}$ gibi bir çok farklı inançlar doğrudan doğruya Paulus teolojisinin kaynaklık ettiği inançlardır. Özellikle Havarilerce Yahudi dinini tamamlamak için gelmiş olduğuna inanılan Hz. İsa’nın (Matta 15,24), Paulus’un Yahudi dininin kurallarını kaldırmak için geldiğini söylemesi, eskiden beri süregelen dinin kurallarının günahın nedeni olduğunu iddia etmesi, insanın günahkar doğmasının Tanrı tarafından oğlunu kurban etmekle bütün insan topluluğunun günahlarına kefaret olduğunu inanç esası kabul etmesi gibi bu günkü Hıristiyanlığın da temel inançlarını temsil eden bu anlayış ve inanç, cemaatin de ikiye bölünmesine neden oldu. Bu iki guruptan Paulus ile ihtilaf edenlerin oluşturduğu guruba dinler tarihinde Yahudi-Hıristiyanlar ya da Ebionitler denilir. ${ }^{14}$

${ }^{10}$ Saint Paulus, başlangıçta Hz. İsa ve cemaatinin en büyük düşmanlarından ve Roma ihbarcılarından biriydi. Yine böyle bir ihbar için Suriye'ye yolculuk ederken, kendi anlatışı ile, Şam yolunda gökte Hz. İsa'yı görür ve 'Beni niçin incitiyorsun?' sözünü duyar. Bunun üzerine muhbirlikten vazgeçerek Hıristiyanlık dinine girer ve kendisinin de havari olduğunu ve putperestleri irşat için Hz. İsa tarafından görevlendirildiğini iddia eder. Bu olaydan sonra Havariliğin Ölçütü konusunda ihtilaflar ortaya çıkar.

11 İlk Hıristiyanlar dönemindeki bu ihtilaflar, daha sonraki dönemlerde yapılan yorumların, yine başlangıçta olduğu gibi çoğunlukla inançla sınırlı olmasına, yani geleneksel olarak inanılana ters olmamasına ve İncil içindeki ifadelerden çok, yukarıda anlatıldığı ve yine gösterileceği gibi, belirli problemler etrafinda odaklanmasına neden oldu. Tarihsel olarak bazı olayların doğru tespiti mümkün olsaydı, görülen o ki, şu andaki yorumların büyük bir kısmına gerek olmayacaktı. Tarihsel olarak ortaya çıkarılamayan ya da iki farklı rivayet arasında seçim yapılmasında bir tercih ettirici doğru neden bulunamayan olaylar yorum konusunun ister istemez belkemiğini oluşturmuştur.

${ }^{12}$ Yahudilik Hz. Üzeyr'e karşı olana tutumları nedeniyle tanrının oğlu kavramına çok uzak olmamakla beraber o dönemde böyle bir fikrin ileri sürülmesi korkunç bir durumdu.

${ }^{13}$ Paulus ile birlikte putperest kökenli Hıristiyanlara yönelik irşat görevi, Paulus'un bazı inanç esaslarını da yaymasıyla devam etti. Bunlardan en önemlilerden birisi 'Tanrının Oğlu' kavramından sonra 'Komünyon ayini' yani Hz. İsa'nın Zeytin dağındaki son vaazındaki ekmek ve şarapla ilgili hatırasıydı. Görüşleri nedeniyle Paulus, Yahudi-Hıristiyanlar yani Ebionitler tarafından nefretle karşılandı (Raisanen 2001:85).

${ }^{14}$ Ebionitler ya da Yahudi-Hıristiyanlar, ilk bakışta Yahudi kökenli Hıristiyanlar anlamına gelir. Fakat tam olarak anlamı Paulus teolojisinin ortaya çıkardığı inançlara muhalefet eden ilk kiliseyi temsil eder. 
Ebionitlere göre, Paulus'un Şam yolundaki vizyonu onu havari yapamaz, çarmıha gerilmek hidayet sembolü olamaz. Kanlı kurban putperestlik inancında bulunur. Hz. İsa Yahudiliğin ıslahçısıdır, yoksa bütün Yahudiliği ortadan kaldırmak için gelmemiştir, o kanlı kurbanların düşmanıdır. Ayrıca Tevrat saflığını koruyamamıştır.

İlk cemaatin başkanı konusu da bu nedenle ihtilaf konusudur. Ebionitlerce ilk başkan Hz. İsa'nın kardeşi Yakobus, Katoliklerce Havari Petrus'tur ${ }^{15}$. Bütün bu inanç farklılıkları nedeniyle Ebionitler, hem Yahudiler hem de diğer Hıristiyanlar tarafından dışlanmışlar, Pella ve sonra da Bar Kochba şehirlerine göç ettilerse de Roma ve Yahudi takibatı nedeniyle birkaç yüzyıl sonra tarihten silindiler. ${ }^{16}$

\section{Mezhepler ve Anlayışları}

Yukarıda anlatıldığı gibi, cemaat içindeki ilk ihtilaflar Paulus'un topluluğa girmesiyle başladı. Paulus'un liderliğini yaptığı topluluk, ağırlığı putperestlere verdi ve Hıristiyanlık putperest dinlerin yaygın olduğu Roma İmparatorluğu'nda hızla yayıldı. Takibatların şiddetlenmesine rağmen üç asır sonra Konstantin Hıristiyan olmadan önce Hıristiyanlığa hürriyet verdi ve yavaş yavaş Roma İmparatorluğunun kanunları Hıristiyanlığa göre değiştirildi. Kiliseye alışılmamış yetkiler verildi. ${ }^{17}$

4.a. Marcion: Paulus'un teolojisi üzerinde büyüyen ve putperestlere yönelik davet çalışmaları nedeniyle hızla yayılan Hıristiyanlık içine giren putperest kökenli

Başlangıçta tamamı Yahudilerden meydana gelmişse de, sonradan bu inanca Yahudi olmayanlar da dahil olmuştur. Hıristiyanlığın ilk temsilcileri olan Ebionitler, Yahudi dinindeki kurallardan vazgeçilmesini ve Hz. İsa'nın tanrısallığını kabul etmediler, daha sonra mensubu sayıca büyük olan kilise tarafından reddedildiler (Waddington 1833:VIII). Ebionitlerce Hz. İsa Hz. Meryem'in bir erkekle olan normal evliliğinden doğmuş, diğer insanlardan farklı olmayan bir kimsedir. (Waddington 1833:66)

15 Paulus ile havari Petrus arasında çıkan şiddetli tartışmalar şu problemlere dayanmaktaydı: Petrus diyordu ki “sen Hz. İsa’yı Şam yolunda gördüğünü ve dini ondan öğrendiğini söylüyorsun. Öyleyse öğrendim dediklerin niçin bizim öğrendiklerimize ters. Sen dini Hz. İsa'dan öğrendiysen biz kimden öğrendik? Hem sen havari olduğunu söylüyorsun. Öyleyse neden havarilerle çatışıyorsun? Hem sen onun düşmanıydın. Neden sana gözüksün? Hem bir defa Hz. İsa’yı görmekle oluyorsa, Hz. İsa niçin bizimle senelerce dolaştı?.. Bu tartışmaların sonucunda Paulus cemaatten "deccal” denilerek kovulmuştur.

${ }^{16}$ Günümüzdeki Hıristiyanlık tümüyle Paulus teolojisi üzerinde şekillenmiştir. Şu andaki İnciller de Paulus taraftarlarınca yazılmış olan İncilleridir.

17 Büyük Teodosius zamanında putperestlik yasaklandı, 529 yılında İmparator Jüstinyen Atina'daki Platon'un Akademisi'ni putperest olduğu gerekçesiyle kapattı (Sarıkçığlu 1982: 231). 
olanlar, eski inançlarını tümüyle silemediklerinden, eski inançların ister istemez yeni problemlere etkisi oluyordu. $^{18}$

Bu dönem içinde M.S. 140 yıllarında Paulus'a aşırı sadakatiyle ortaya çıkan Marcion, (Boer 1976:60) Paulus kökenli Hıristiyanların inançlarını aşırı şekilde yorumladı. Marcion yaklaşık 144'te kiliseden atılmış, ayrı bir kilise kurmuştur.

Marcion'a göre kurtuluşa, kendisinin Müjde olarak anladığı habere basit bir iman adımıyla kavuşuluyordu. Marcion, Eski Ahid'in Tanrısı'nın kötü olduğunu ve İsa'nın “iyi ağaç hem iyi hem de kötü meyve veremez” (Matta 7,17) sözünü dünyaya atfederek, içinde bu kadar acı ve kötülüğü barındıran bir yerin kötü bir varlığın eseri olması gerektiğini ileri sürmüş̧ür. Bu düşünce Marcion’un yorumlarının hareket noktasıdır. Bu kötü yaratıcıyı da Gnostikler'in de kullandığı Platonik Demiurgos terimiyle tanımlamış ve dünyanın yanı sıra insanın da bu kötü tanrının eseri olduğunu söylemiştir. ${ }^{19}$ Marcion aynı zamanda Mesih'in bir bedene sahip olmadığını sadece bedeni varmış gibi yaptığını söylemiştir. $^{20}$

Marcion ayrıca Müjde bölümlerinden de sadece bir tanesinin yetkin olabileceğini savunarak kararını Luka bölümünde vermiştir. Luka bölümünü de diğer düzeltilmiş Pavlus mektupları parçalarına eklerken savunduğu Müjde’ye gölge düşürebilecek bazı kısımlarını da temizleyerek, kendisine göre ilk kutsal kitap olarak kilisesine sunmuştur. $^{21}$

Zor şartlara rağmen Marcion özellikle imparatorluğun doğu kesimlerindeki kiliselerde geniş bir izleyiciye sahipti ve 5.yüzyıla kadar yer yer devam etmiştir.

\footnotetext{
${ }^{18}$ Eski adet ve geleneklerin, inançların Paulus teolojisi içine girmeleri, Paulus teolojisinin, İncillerden gelen inancın çerçevesiyle ilgili zorunlu kurallarının bulunmamasından kaynaklanmaktaydı. İncillerde Hz. İsa'nın hayat hikayesi ve bazı ahlaki öğütlerin dışında pek az kural bulunması nedeniyle yeni yorum yapılmasina bir sinırlama konulamiyordu.

${ }_{19}$ Yalnız bu konuda belki de Gnostikler'den etkilendiği için, kendisi ile çelişerek ruh-beden arasında bir zitlık da görüyordu.

${ }^{20}$ Doketizm olarak bilinen bu inanca Gnostikler arasında da rastlanmıştır.

${ }^{21}$ Bu yaptığı ile aslında kilise tarihinde ilk kutsal kitap sıralaması yapan kişidir. Bu sayede kilise de doğru Kutsal Kitap listesini yapmak için ayağa kalkmıştır.
} 
$\mathrm{Bu}$ yorumlamalara göre özetle, dünyayı yaratan Ulu Tanrı değil, başka bir varlıktı. Demiurg'tu. Hz. İsa’nın babası değildi. Dünya Yahudi Tanrısı tarafından yaratılmıştı. Eski Ahid'in Hıristiyanların inançlarından çıkarılması gerekliydi. İncil deyince Eski ve Yeni Ahid'in bütün kitapları akla gelmektedir. Marcion bu kitapların birliğini reddetmişti (Chadwick 2003:104). Marcion'a göre, Luka İncili, Havariler Tarihi ve Paulus'un Mektupları dışında Hıristiyanlar için kutsal bir kitap olamazdı.

Marcion bu görüşleri nedeniyle kilise içinde gnostisizmin tehlikeli en büyük temsilcisi olarak görüldü (Boer 1976:61) ve kilise tarafından zındıklıkla suçlandı. Bunun üzerine müstakil olarak kurduğu kilise de daha sonra imparatorun zındıklar hakkındaki kanunuyla tarihten silindi. ${ }^{22}$

4.b. Arius ve Athanasius: İskenderiye'de doğmuş ve kendi adıyla anılan (Arianism) mezhebi kuran Arius, İnciller hakkında ortak bir kararın, yani ortak bir İncil üzerinde anlaşmanın olmadığı, bir çok incilin farklı guruplarca Hıristiyanlık inancı olarak elde bulundurulduğu bir tarihte (Montague 1997:29) 'Kelam'ın (Hz. İsa'nın) tanrısal bir varlık olmadığını ileri sürerek, Hıristiyanlıkta sapkın kabul edilen bir kurumun ve Hıristiyanlık tarihinin en büyük olayının doğmasına neden olmuştur. ${ }^{23}$

\footnotetext{
${ }^{22}$ Marcion'un görüşlerine itirazda İnciller kaynaklı bir gerekçe göstermek büyük bir problem olmuştur. Marcion'a itiraz kararının tek gerekçesi bu inançlar aleyhine bir ortak kilise kararının alınmış olmasıdır. Bizi ilgilendiren tarafı, bu reddiye kararının, belirli bir kurallar bütününe ters düşüp düşmediği noktasıdır. İncillerin yorumunda göz önüne alınması gereken çok önemli bir nokta vardır; o da, İncillerdeki cümlelerin, hükümlerin ya da emirlerin söylenme amaçları ve söylendiği olaylarla ilgili bir kaydın bulunmamış olmasıdır. Bu nedenle yorumları sınırlayıcı bir kriterden söz etmek imkanı yoktur. Marcion'un aforoz edilmesinde (Boer 1976:62) ve görüşlerinin de bu açıdan reddedilmesinde kesin olarak gösterilecek İncile dayalı, aşırı yorumu sınırlayıcı bir hüküm yoktur. Kilise, istişarelerinde kutsal ruhun hazır olduğuna inanır, bu nedenle oy çokluğuyla alınan kararın aslında kutsal ruhun sevkiyle olduğunu kabul eder. Tartışmaları yönlendiren ana unsur ise Paulus'un görüşleriydi.

${ }^{23}$ Arius'un yaşamının ilk dönemi hakkında ayrıntılı bilgi yoktur. 'Kilise Babaları Felsefesi' denilen akımın öncülerinden Diogenes'in yapıtlarını incelemiş, yine bir 'Kilise Babası' sayılan Antakyalı Lukianos'un öğrencisi olmuştur. Bir süre sonra Kilisenin dini görüşlerini eleştiren, Hıristiyan anlayışına karşı çıkan ve bu nedenle kiliseden ayrılan Meltios'un görüşlerini benimsemiş ve paylaşmıştır. Daha sonra Kilise ile arası düzelmiş ve papazlıkla görevlendirilmişse de halkı aydınlatmak için verdiği vaazlarda, Hıristiyan inancının Tanrı olarak benimsediği "Kelam"ın Tanrı olamayacağını, tanrısal bir güç olarak bile sayılamayacağını ileri sürmüştür. Kendisine yapılan tüm uyarıları dinlememiş ve sonunda kilisedeki görevinden alınmıştır.
} 
Mısır'dan ayrılıp önce Filistin'e daha sonra Bithynia'ya giden Arius, düşüncelerini oralarda yaymaya çalıştı. İzmitli Eusebios ile de tanışarak görüşlerini ona da benimsetmiş, böylece daha güçlü ve etkili bir tartışma ortamı oluşmasını sağlamıştır. Bu tartışmanın kısa sürede geniş bir coğrafyaya yayılması, kiliseyi sıkıntıya sokunca, İmparator Constantinus olaya karışma gereğini duydu. Tartışmaların kesilmesi, dargınlıkların giderilmesi, kilise büyükleriyle yeniden barışılması uyarıları sonuç vermeyince, Arius, Hıristiyan dininin temel ilkelerine, özüne aykırı görüşleri nedeniyle, ki bu özden kasıt Paulus'un görüşleridir, 325 yılında İznik Konsili'nce aforoz edildi. Düşüncelerini topladığı 'Thalia' adlı kitabı yasaklandı. Bu yasaklamadan dolayı Arius ile ilgili bilgilerimizin çoğu kendi el yazmalarından ziyade, onun muhalifleri tarafından yazılmış kitaplara aittir (Rowan 202: 95). ${ }^{24}$

Kilise'nin 'Baba-Oğul-Ruh' üçlemesine bağlanan ve bu üçlemeyi somutlaştıran inanc1; görüşlerini akıl ilkelerine dayandıran, imanı aklın denetimi altına veren Arius için, doğaya da insan düşüncesine de aykırıydı. Kiliselerin Doğu-Batı diye ikiye ayrılması bile Hz. İsa'nın tanrılığını akıl yürütme ile reddeden Arius'un (Rowan 2002:98) ortaya attığı düşüncelerin yayılmasını, birtakım yeni inanç kurumlarının doğmasını engelleyemedi. ${ }^{25}$ Tanrı'nın tek varlık olduğuna inanan ve üçlemeyi gerçek saymayan akımların çoğu Arius'un görüşlerinden etkilenmiştir. ${ }^{26}$

İskenderiyeli iki tanrıbilimci olan ve teslisi savunan Athanasius ile teslisi Hıristiyanlığa ve akla ters bulan ve bu öğretiyi yaymakla kiliseyi suçlayan Arius arasındaki bu tartışmanın bütün Hıristiyan kilisesine yayıldığını ve ilk konsilin İznik’te

\footnotetext{
${ }^{24}$ İznik Konsili bu yasaklamayla da yetinmemiş, Ariusçuluk'a karşı Hıristiyan inançlarını savunan bir kitap hazırlatarak kiliselere dağıtmıştır. Bu kitaba göre; "İsa, Tanrı'nın tek oğludur, bütün çağlardan önce Baba olan Tanrı'dan doğmuştur. İsa Tanrı'nın Tanrısı, ışı̆̆ın ışı̆̆ı̆dır, gerçek Tanrı'nın kendisidir. Doğmuştur ancak yaratılmamıştır, Tanrı ile bir tözdendir, özdeștir, bütün işleri yapan, yaptıran odur"

${ }^{25}$ Ariusçuluk, başta Mısır olmak üzere, Vandallar, Vizigotlar, Ostrogotlar ve Lombardlar gibi (üçlemeli) Hıristiyanlığa iyice ısınamamış topluluklar arasında hızla yayıldı. Venedik'te, Avrupa'nın değişik ülkelerinde birçok Ariusçu kuruluş ortaya çıktı. Bunlara 'Oniter' adı verildi.

${ }^{26}$ Arius'un düşüncelerini felsefenin eleştiri konusu yapan, onlara karşı Kilise'nin görüşlerini savunan ilk kilise babası Augustinus olmuştur. Augustinus, Arius'un özellikle 'üçleme' konusunda ileri sürdüğü düşüncelerin yalnız Hıristiyan inançlarına değil, bu inançlardan kaynaklanan ve akıl ilkelerine dayanan felsefeye bile aykırı düştüğünü söylemiştir. Bu sözlerin etkisi büyük olamamış tam tersine Arius'un daha çok ilgi çekmesini sağlamıştır.
} 
toplanmasına neden olduğunu belirtmiştik. Bu ilk büyük konsil henüz Hıristiyan olmamış Konstantin'in imparatorluk içindeki bu iki büyük Hıristiyan gurup içindeki tartışmaları bitirmek amacıyla ve onun isteğiyle yapılmıştı. Tanrı Kelamının tenleşmesi ve İsa'da kalması konusunda mutabık olmakla birlikte (Bazı tarihçiler bu görüşte değildir), kelamın doğasını farklı şekilde algılıyorlardı (Michel 1992:99). Athanasius’a göre Tanrı Kelamı, yani İsa’da tenleşen Tanrı Sözü yaratılmamıştı, baştan beri Tanrıyla birlikteydi. $^{27}$

Konstantin, Hıristiyanlar arasındaki bu tartışmaya son vermek için M.S. 325'te İznik'te topladığı konsil Arius'un görüşlerinin Konstantin'in müdahalesiyle reddedilmesi sonucunu doğurdu. Ölçüt olarak Paulus’un görüşlerine başvuruldu.

Arius’un bu görüşünün reddedilişinin nedenine bakılırsa ${ }^{28}$, onun dışlanmasının altında yatan nedenin, Konstantin'in müdahalesi dışında, Arius’un görüşlerinin Paulus'un görüşlerine ters düşmesi olduğu görülmektedir. ${ }^{29} \mathrm{Bu}$ ilk konsilin, yani İznik Konsili'nin bu şekilde sonuçlanmasıyla, günümüze kadar sürecek olan Paulus görüşlerinin hakimiyeti anlayışının her problemin yorumlanmasında vazgeçilmez kriter olması olgusu geri dönülmez şekilde onaylanmış oldu. Bu konsilden sonra her türlü tartışma ve yorumda ölçüt Paulus'un görüşleri oldu. ${ }^{30}$ İznik Konseyi'nin konusu, İsa'nın sadece bir insan olup olmadığı değildi. Bunun yanı sıra İsa'nın Tanrı mı, yoksa herhangi

\footnotetext{
${ }^{27}$ Arius’a göre, Tanrı Kelamı ezeli değildi. Tanrı tarafından evren yaratılmadan önce, ama zaman içinde yaratılmıştı. Yani İsa'da yaratılmamış Kelam değil bir yaratık tenleşmişti.

${ }_{28}$ Arius'un görüşleri ve İsa yorumu neden büyük tartışmalara neden olmuştur? Bu nedeni anlamak için Kelamın ezeli sayılmamasının ne anlama geldiğine bakmak gerekir:'Kelam'ın ezeli olmaması, onun yaratılmış olduğu anlamına gelmesi; yaratılmış olması da, yaratılmışın hataya açık olması, hatâya imkan tanıması ve dolayısıyla tanrı olmaması gibi Hz. İsa'ya atfedilebilecek sonuçlara neden olduğundan, bu yorum Paulusçu Hıristiyanlık anlayışına oy çokluğuyla ters bulundu.

${ }^{29}$ Kabul edilen İnciller de Paulus'un görüşleri doğrultusunda yazılmış İnciller oldukları için, reddedilme gerekçesinin sadece Paulus'un görüşleri doğrultusunda şekillenen inançlara ters düşmemek anlayış1 olduğu görülecektir. Çünkü hiç kimse kendi iddiasını ispatlamak için başka bir kriter göstermemiştir. Arius'un akıl esaslı İsa anlayışına hiçbir akli gerekçe ile muhalefet edilmemiştir. Karar oy çokluğuyla alınmıştır.

${ }^{30}$ Arius'un, Mesih'in tanrısallığını reddedince bu konunun kilise içerisinde büyük bir teolojik tartışmaya dönüşmüş olması kilisenin Mesih'in tanrısalığını daha önce bu şekilde tartışmamış olduğunu gösterir. Yoksa Arius'un öğretisi hemen reddedilirdi. İznik Konseyi bu anlaşmazlığı ortadan kaldırmak maksadıyla, topluluk önderlerinin bir araya gelme kararıdır. Mesih'in tanrısallığı tüm önderlerce onaylanmıştır. Arius ve destekçileri topluluk önderleri arasından atılmıştır.
} 
bir ilah mı olduğunu da tartışıyorlardı. Bu toplantıda alınan kararlarla ortaya konulan "İznik İman Bildirisi" kararı, bugünkü Hıristiyanlar için de geçerli kabul edilmiştir. ${ }^{31}$

İznik İman Bildirisi olarak bilinen bu bildiri, sadece Arius'un öğretişine karş1 çıkmak amacıyla beyan edilen Üçlübirlik tanımı değil, fakat aynı zamanda tarihteki ilk Hıristiyan iman bildirisidir. (Bu bildiri halâ Ortodoks, Roma Katolik, Luteran ve Episkopal Kiliseleri'nin ayinlerinde kullanılır). Arius'un öğretişleri, tüm Hıristiyanlık tarihi boyunca Mesih İnanlıları'nın yeni mantık kavramlarıyla uğraştıklarını gösterir. ${ }^{32}$

4.c. Nestorius: Suriyeli bir piskopos olan Nestorius, Hz. İsa'da biri insani, biri de ilahi olmak üzere gerçekten de iki şahıs var olduğunu, insani şahsın Meryem'den doğduğunu, İlahi şahsın ise tanrının ebedi kelamı olduğunu ileri sürüyordu (Michel 1992:100). ‘Tanrı Kelamı’ ile ‘İsa’ aynı anlama sahip değildir (Loofs 1914: 91).

Nestorius'un, bu farklı görüşünün İncillerden gösterilecek bir kaynağı olmadığı gibi, M.S. 431 yılında Efes’te toplanan Efes Konsili'nin de bu görüşü reddetmesinde İncillerden bir kaynak gösterilmemiştir. Fakat tartışmaların Paulus görüşleri açısından değerlendirildiğini biliyoruz. Reddiye kararı yine oy çokluğu ile alınmıştır. ${ }^{33}$

4.d. Evtiches: Nestorius'un aksine Hz İsa'da iki değil tek şahıs varolduğunu ve bunun da sadece tanrısal olduğunu ilan eden Evtiches, (Michel 1992: 101) 451 y1lında yapılan Kadıköy Konsili'nde (Kalkedon) yine oylama ile reddedildi. Evtiches'in bu Monofizit öğretisi, Kadıköy Konsili tarafından reddedilmekle, ilk iki konseyin, yani İznik ve Efes Konsillerinin kararları da onaylanmış oldu.

\footnotetext{
${ }^{31}$ Bunlar: 1. Mesih Tanrı'nın Kendisiydi. 2. Mesih Baba'yla aynı öze sahipti. 3. Mesih Tanrı'nın 'biricik' Oğludur, yaratılmamıştır. 4. Mesih, insanların kurtuluşu için insan bedeni almıştır.

${ }^{32}$ Arius'un savunduğu nokta şuydu: Eğer Baba Tanrı kesinlikle yetkin, üstün ve değişmeyense ve her şeyin kesin yaratıcısıysa, o halde yeryüzündeki her şey ve herkes, Tanrı'dan ayrı tutulmalıdır. Ve Arius varsayımına şunu eklemiştir; eğer her şey Tanrı'dan ayrılıyorsa, o halde İsa da Tanrı'dan ayrılmalıdır. Arius ve izleyicileri, Mesih'in dünyaya gelmeden önce var olduğuna ve Mesih'in dünyanın yaratıcısı olduğuna inanıyorlardı. Arius'a göre, İsa dünyanın yaradılışında ve kurtuluşunda büyük bir rol oynamıştı, fakat Kendisi Tanrı değildi. Sadece tek bir Tanrı olabilirdi. Bu yüzden Mesih mutlaka yaratılmışlardan olmalıydı. Bu nedenle, Mesih de değişebilir ve günah işleyebilirdi (tüm yaratılanlar gibi)... ve Mesih de Tanrı'nın aklına sahip değildi.

${ }^{33}$ Efes konsilinin red kararına rağmen Nestorius'un görüşleri yine de taraftar buldu ve günümüze kadar devam etti. İran ve Suriye'deki Nesturi kiliseleri Nestorius'u aziz olarak tanımaktadırlar (Loofs 1914:1).
} 
Roma ve İstanbul Kiliseleri, bu kararı kabul ederken, Mısır (Kıpti) ve Suriye Kilisesi (Yakubiler) bu kararı kabul etmedi. O tarihten bu yana Kıpti ve Süryani Ortodoks Kilisesi ile Roma Katolik Kilisesi arasında birlik son buldu. ${ }^{34}$

4.e. Augustinus: "Anlamak için inanıyorum" diyen Augustinus önceleri Maniehist, sonra Yeni Platoncu, daha sonraları Hıristiyanlı̆̆a geçerek Kuzey Afrika'nın liman şehri olan Hippo'nun piskoposu olmuştur.

Augustinus'un en önemli öğretisi kiliseyi Kitab-1 Mukaddes'in üzerinde tutmasıdır. "Eğer Katolik kilisesinin otoritesi beni harekete geçirmeseydi İncillere inanmazdım" diyor. Augustinus'in yine önemli düşüncelerinden biri, lüzumlu amelde bulunulursa ve vaftizle bütün günahların affedileceği görüşüydü. Bu affetme işi de ancak kiliseye aittir, buna inanmak gereklidir.

Kilisenin günahlardan kurtulmak için veya kurtarmak için yapılan ayinler, azizlerin iyi amel hazinelerini topladıkları tasavvurunu doğurdu (Sarıkçıoğlu 1992:240). $\mathrm{Bu}$ görüşler ortaçağın sonlarına doğru kilisenin bu anlayışın ticaretini yapmasına ve Reform kilisesinin doğmasina neden oldu. ${ }^{35}$

Ancak Augustinus ile başlayan Yeni Platonculuğun etkisiyle, Hıristiyan dünyası başlangıçta, İbni Rüşd'ün eserleri ile Avrupa'ya yayılmaya başlayan Aristoteles felsefesini reddettiler. Daha sonra İbni Rüşd'ün akıl ve nakil ilişkisi kavramına ilişkin yaklaşımları ile bilgiye ulaşmanın birinci olanağının akıl olduğu sonucuna vardılar.

\footnotetext{
${ }^{34} 1970$ yılında Kıpti Kilisesi ile Roma Katolik Kilisesi arasında imzalanan bir anlaşma ile tanrıbilimsel ayrımlara son verildi. Ermeni Kilisesi ise bu ayrımı reddetti.

${ }_{35}$ Augustinus'un Hıristiyanlığa en önemli katkısı, felsefenin meşru bir Hıristiyan bilimi gibi Hıristiyanlıkta kabulüne zemin hazırlamıș olmaktır. Bu tarihten sonra felsefe, daha dar bir anlamda Platon ve Plotinus, çok sonraları da Aristoteles, Hıristiyanlı̆̆ın inanç esaslarının şekillendirilmesinde vazgeçilmez unsurlar durumuna geldi. İncillerden ve İncillerde anlatılan Hz. İsa'nın hayatından inanç esasları ile ilgili göz önüne alınması gereken emir ve tavsiyelerin son derece kısıtlı olması nedeniyle, gün geçtikçe büyüyen ve sürekli tartışmalara bölünmelere ve yeni yeni mezheplerin doğmasına yol açan bu boşluk felsefe ile kapatıldı. Hz. İsa'nın tanıının oğlu olması ve kendisinde tanrısallığın ve insaniliğin aynı anda bir araya gelmiş olması, kendisini insanların Hz. Ademden dolayı yüklendikleri günahlara kefaret olarak kurban etmesi gibi dogmalara dokunulmamak şartıyla, her türlü felsefi yorum Hıristiyanlığın fikri alt yapısını oluşturdu. Hıristiyanlık, başlangıçta kilise babalarının anlayışlarına, Augustinus'tan sonra da yavaş yavaş felsefenin sistematik düşüncelerine bırakıldı. Fakat bir Hıristiyan felsefesi oluşturma yönündeki çabalar Rönesans ile birlikte sona erdi (Michel 1992: 142).
} 
Albertus Magnus ile Augustinusçuların aksine, Aristoteles felsefesinin Hıristiyanlık tanrıbilimine en uygun felsefi temeli sağladığına karar verildi. ${ }^{36}$

Augustinus’un kiliseyi İncillerin önüne çıkaran öğretisi, Katolikliğin en önemli kurallarından biri durumuna geldi. Günahı ancak kilisenin affedebileceği, bunun için sadaka ve kurban gibi kilise eliyle yapılacak ibadetlerin yardımcı olabileceği gibi görüşler Katolik Kilisesi içinde suistimal edilerek ticarete dönüştü. Endüljans

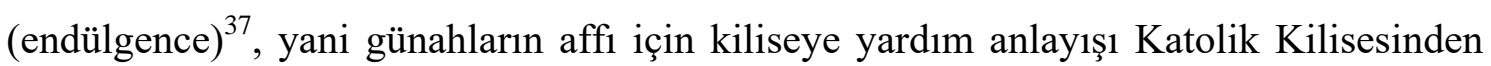
kopmalara neden oldu. ${ }^{38}$

\section{Sonuç}

Hıristiyanlığ şifahî Hıristiyan nakline göre Hıristiyanlığı ve İncil'i bir mucize ile İsa'dan aldığını söylemiş, ileride kilisenin talimlerine İsa'dan aldığını söylediği görüşleri hâkim kılmak için gayret sarf etmiştir. Yahudi olduğu halde Roma vatandaşı olan (Ramsay 2001:35) ve diğer havarilerden farklı olarak eski kitapları bilen Paulus, zeki ve zamanının bütün dinî cereyanlarını bilen bir insandır. Diğer dinlerden birçok hususları Hıristiyanlığa aktarmıştır.

Paulus, İsa'nın ve Ruhu'l-Kuds'ün Tanrı oldukları inancını yerleştirmeye çalışmıştır. Ayrıca yine O, İsa'nın vazettiği sünnet olmayı ve domuz eti yememeyi de kaldırmıştır. Bir bakıma bugünkü Hıristiyanlığa Paulus'un yorumları demek mübalağalı bir ifade olmaz. Nitekim, gerek mukaddes metinler gerek ilk kilise, gerek ilk Hıristiyan

\footnotetext{
${ }^{36}$ Hıristiyanlıkta yapılan yorumlar tümüyle inanç esaslarının tanzimine ilişkindir. Bu kural hiçbir devirde bozulmamışıtır. Ahlak ilkeleri büyük çoğunlukla kilise babalarının anlayışlarından çıkarılmıştır. Daha sonra anlatılacağı gibi birinci cümleden son cümleye kadar devam eden, bazı görüşleri ispatlama çabasından öteye gitmeyen İncil yorumlarının pek bulunmamasının en büyük nedeni, İncillerin tercümelerinin aslı ile aynı kabul edilmeleridir.

${ }^{37}$ Kilisenin günahları sadaka ve makbuz karşı1lığı bağışlaması

38 Katolikliğe göre, kilise Hz. İsa'nın vücududur. Hz. İsa'nın yetkisi Papa'da, sınırlı olarak da piskoposlarda vücutlaşmıştır. Hıristiyanlığı ilgilendiren bütün konularda Papa tek otoritedir ve yanılmazdır. İncilleri ancak kilise anlayabilir ve yorumlayabilir. Halkın İncilleri anlaması kilise aracılığıyla mümkündür.
} 
inançlarının Paulus'un eseri olduğunda Hıristiyan ilâhiyatçıları görüş birliği içindedirler. Calvin'in yorumları da Paulus'un görüşleri doğrultusunda ortaya konulmuştur. ${ }^{39}$

Luther ile başlayan reformlar ${ }^{40}$ Katolik kilisesine ve onun İncil üzerindeki otoritesine itiraz olarak yapılmıştır. Katolik kilisesindeki uygulamalar ve Katoliklik etkisindeki kilisenin genel kutsal kitap anlayışı, İncil üzerinde kiliseyi mutlak otorite durumuna getirmişti. İncili ancak kilise yorumlayabilirdi ve halkın günahlarını ancak kilise affettirebilirdi. Kilise hem dünya işlerinde hem de din işlerinde mutlak otoriteydi. Din adamlarının tayinleri doğrudan kilise tarafından yapıldığ 1 gibi, krallıkların meşruiyeti de ancak kilisenin onaylaması ile kazanılabiliyordu. Kilisenin maddi manevi hakimiyeti, Saint Augustine'nin kiliseyi incilin önünde tutan görüşlerinin esas alınmasından kaynaklanmaktaydı. Hıristiyanlığın inançları Saint Paulus tarafından şekillendirildiği gibi, kilise uygulamaları da çoğunlukla Saint Augustinus’un görüşleri doğrultusunda şekillendirilmişti. Luther'in 95 maddelik bildirisi Katolik kilisesinin uygulamalarına, dolayısıyla Saint Augustinus'un görüşlerine yönelikti.

Hıristiyanlık yorum tarihinin problematik kaynakları şu şekilde özetlenebilir: Yahudilik-Hristiyanlık ilişkisi, Hz. İsa'nın mahiyeti, tebliğin kimlere yönelik olacağı, eski ve yeni inananların hangi şeriata tabi olacakları, havarilik meselesi, resim ve heykellerin kudsiyeti konusu, kitapların kutsallığının ve birden çok İncil bulunması meselesi, İncillerin ve kilisenin bir Hristiyan için ne ifade etmesi gerektiği, incil yorumlarının sınırı, konsillerin durumu, felsefenin inanç içindeki yeri, teslis problemi, ebionitlerin durumu.

$\mathrm{Bu}$ problemlerin her birisi Hıristiyanlık tarihinde bir dönem büyük sarsıntılara sebep olmuş ve son haddede Paulus ekolünün başarısıyla son bulmuştur. Mevcut Hiristiyanlık bu problemlerin her birine taraftar olan sayısız mezhep tarafindan temsil

39 Paulus'un, Hıristiyanlık için değişmez prensipleri şunlardır:1-Hıristiyanlık bütün insanlığa hitap eden bir dindir. 2-Tanrının oğlu olan Mesih İsa, insanların günahlarına kefaret olmak üzere Haç'ta can vermiştir. 3-İsa ve Ruhu'l-Kuds, aynı derecede Tanrıdır. 4-Ölüler arasından dirilerek kalkmış olan İsa, semaya çıkarak babasının sağ yanına oturmuştur.

${ }^{40}$ Luther'in reformu üç noktaya odaklanmıştır. Birincisi incili yorumlamak kilisenin tekelinde değildir. İkincisi, kilise dünyevi işlerden soyutlanmalıdır. Üçüncüsü, tanrı ile kişi arasında vasıta bulunamaz. Bu görüşler Protestan teolojinin Paulus'a ek olarak ölçütleri durumuna gelmiştir. 
edilmektedir. Hıristiyanlık hakkındaki her türlü felsefi veya din temelli bir çalışma tüm bu tarihi problemlerin bilinmesini şart koşmaktadır. Augustinus'tan itibaren felsefe ve Hristiyanlık iç içedir. Hatta felsefenin bir çok kavramı doğrudan Hıristiyanlık düşüncesine aittir. Bu kavramların kökeni bilinmezse filozof değerlendirmeleri ister istemez eksik ya da yanlış olacaktır. 


\section{KAYNAKÇA}

BOER, Harry R. (1976). A Short History of the Early Church, Michigan: Wm. B. Eerdmans Publishing.

BESANÇON, Alain (2000). The Forbidden Image, trans. by Jane Marie Todd, Chicago and London: University of Chicago Pres. Press.

CHADWICK, Henry (2003). The Church in Ancient Society, Oxford University

DAVIS, Leo Donald (1990). The First Seven Ecumenical Councils (325-787): Their History and Theology, Minnesota: Liturgical Press.

HARRINGTON, Daniel J. (1991). The Gospel of Matthew, Minnesota: Liturgical Press.

HARMAN, Ö. Faruk (1996). "Katolik Kilisesi ve Teokrasi”, Din-Devlet İlişkileri Sempozyum Kitabı, İstanbul.

İNCİL-İ ŞERİF İLE TEFSİRİ (1865). (Osmanlıca), İstanbul: Artin Matbaası.

İNCIL (1999). United Bible Societies, İstanbul: Ohan Matbaas1.

LOOFS, Friedrich (1914). Nestorius and His Place in the History of Christian Doctrine, Cambridge: Adamant MediaCorporation.

LUTHER, Martin (1987). Commentary on Galatians, Cambridge: Kregel Publications.

MONTAGUE, George T. (1997). Understanding The Bible: A Basic Introduction to Biblical Interpretation, Paulist Press. Basımevi.

MICHEL, Thomas (1992). Hıristiyan Tanrı Bilimine Giriş, İstanbul: Ohan

RAISANEN, Heikki (2001). Challenges to Biblical Interpretation, Brill Academic Publishers.

RAMSAY, William Mitchell (2001). St. Paulus: The Traveler and Roman Citizen, Kregel Publications. Publishing.

ROWAN, Williams (2002). Arius: Heresy and Tradition, Wm. B. Eerdmans

SARIKÇIOĞLU, Ekrem (2002). Başlangıçtan Günümüze Dinler Tarihi, Isparta: Fakülte Kitabevi.

VERMES, Geza (2005). Ölü Deniz Parşömenleri: Kurman Yazıtları, çev. Nurfen Çelebioğlu, İstanbul: Nokta Kitap. 
Ahmet KAVLAK, "Hıristiyanlıkta İncil Yorumlarının Tarihsel Kaynakları," Kaygl, 18(1)/2019: 240-256.

WADDINGTON, George (1833). A History of The Church From The Earliest Ages to The Reformation, London: Baldwin \& Cradock Publ.

YAZICIOĞLU, Hulusi (1993). Bir Din Politikası Laiklik, İstanbul, Marmara Üniversitesi İlahiyat Fakültesi Yayınları. 